\title{
Chryseobacterium soldanellicola sp. nov. and Chryseobacterium taeanense sp. nov., isolated from roots of sand-dune plants
}

\author{
Myung Soo Park, ${ }^{1}$ Se Ra Jung, ${ }^{1}$ Kang Hyun Lee, ${ }^{1}$ Myung-Sook Lee, ${ }^{1}$ \\ Jin Ok Do, ${ }^{1}$ Seung Bum Kim ${ }^{2}$ and Kyung Sook Bae ${ }^{1}$ \\ ${ }^{1}$ Korea Research Institute of Bioscience and Biotechnology, 52 Oun-dong, Yusong, Daejon \\ 305-333, Republic of Korea \\ ${ }^{2}$ Department of Microbiology, School of Bioscience and Biotechnology, Chungnam National \\ University, 220 Gung-dong, Yusong, Daejon 305-764, Republic of Korea
}

\begin{abstract}
Two Gram-negative, yellow-pigmented bacteria designated PSD1 $-4^{\top}$ and $\mathrm{PHA3}-4^{\top}$, isolated from two sand-dune plant species inhabiting coastal areas in Tae-an, Korea, were subjected to taxonomic investigation. 16S rRNA gene sequence analysis indicated that both isolates should be placed in the genus Chryseobacterium of the family Flavobacteriaceae. The phenotypic properties of the strains were also consistent with their classification into this genus. The levels of $16 \mathrm{~S}$ rRNA gene sequence similarity between strain PSD1 $-4^{\top}$ and other Chryseobacterium species were 95.2-97.2\%; those between PHA3-4 $4^{\top}$ and others were 93.7-97.8\%. The DNA-DNA relatedness data indicated that strains PSD $1-4^{\top}$ and $\mathrm{PHA} 3-4^{\top}$ were clearly different from the nearest species, Chryseobacterium indoltheticum and Chryseobacterium taichungense. The major fatty acids were 13-methyltetradecanoic acid (iso-C15:0), 3-hydroxy-15-methylhexadecanoic

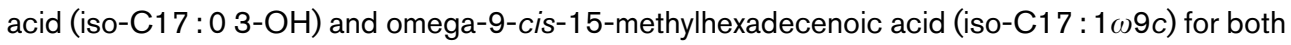
strains. On the basis of polyphasic taxonomic analysis results, it is evident that each of these strains represents a novel species of Chryseobacterium, for which the names Chryseobacterium soldanellicola sp. nov. (type strain PSD $1-4^{\top}=$ KCTC $12382^{\top}=\operatorname{NBRC} 100864^{\top}$ ) and Chryseobacterium taeanense sp. nov. (type strain PHA3-4 $4^{\top}=$ KCTC $12381^{\top}=$ NBRC $100863^{\top}$ ) are proposed.
\end{abstract}

The genus Chryseobacterium currently includes the initially described species Chryseobacterium balustinum, C. gleum, C. indologenes, C. indoltheticum and C. scophthalmum (Vandamme et al., 1994) and several more recently described species, Chryseobacterium defluvii (Kämpfer et al., 2003), C. joostei (Hugo et al., 2003), C. daecheongense (Kim et al., 2005), C. formosense (Young et al., 2005), C. taichungense (Shen et al., 2005), C. shigense (Shimomura et al., 2005) and C. vrystaatense (de Beer et al., 2005). Two former Chryseobacterium species, Chryseobacterium meningosepticum (Vandamme et al., 1994) and Chryseobacterium miricola (Li et al., 2003), have been reclassified in a new genus Elizabethkingia (Kim et al., 2005). Strains belonging to this genus have been found in a wide variety of environments such as soil, sewage, freshwater, marine sediment and clinical samples.

Published online ahead of print on 28 October 2005 as DOI 10.1099/ ijs.0.63825-0.

The GenBank/EMBL/DDBJ accession numbers for the 16S rRNA gene sequences of strains PSD $1-4^{\top}$ and PHA3- $4^{\top}$ are AY883415 and AY883416, respectively.
During a study of bacterial diversity associated with sanddune plants using a culture-dependent approach, a number of bacterial strains were isolated from root samples of two sand-dune plant species (Park et al., 2005). Two strains designated PSD $1-4^{\mathrm{T}}$ and PHA3 $-4^{\mathrm{T}}$, forming yellow colonies on R2A agar (Difco) at $30^{\circ} \mathrm{C}$, were isolated from the roots of Calystegia soldanella (beach morning glory) and Elymus mollis (wild rye), respectively, and subjected to further taxonomic investigation. Analysis of the 16S rRNA gene sequences showed that both of the isolates could be placed within the phylogenetic clade encompassed by the genus Chryseobacterium of the family Flavobacteriaceae. The strains were subcultured on tryptic soy agar (TSA; Difco) at $30{ }^{\circ} \mathrm{C}$ for $48 \mathrm{~h}$ and subsequently investigated for fatty acid methyl ester profiles, 16S rRNA gene sequences and phenotypic characteristics. The strains were also maintained as glycerol suspensions $(20 \%, \mathrm{w} / \mathrm{v})$ at $-80^{\circ} \mathrm{C}$.

Cellular morphology was examined using a Nikon MICROPHOT-FAX phase-contrast microscope with cells grown for 3 days at $30^{\circ} \mathrm{C}$ on TSA. Gram staining was carried out using the modification of Hucker's method as described 
by Gerhardt et al. (1994). Growth was investigated at different $\mathrm{NaCl}$ concentrations $(0-7 \%, \mathrm{w} / \mathrm{v})$, at various temperatures $\left(5-42^{\circ} \mathrm{C}\right)$ and on MacConkey agar. Biochemical tests were performed using the API 20E, API 20NE, API CHB and API ZYM systems (bioMérieux). Oxidation of 95 selected carbon sources was tested using Biolog GN2 microplates according to the manufacturer's instructions. Antifungal activities were screened using four plant-pathogenic fungi, namely Botrytis cinerea, Fusarium oxysporum, Rhizoctonia solani and Pythium ultimum (cultures provided by the Korea Research Institute of Chemical Technology, Daejon, Korea).

Strains PSD $1-4^{\mathrm{T}}$ and PHA3-4 ${ }^{\mathrm{T}}$ were Gram-negative and formed visible colonies (diameter of about $2 \mathrm{~mm}$ ) on nutrient agar within $24 \mathrm{~h}$ at $30^{\circ} \mathrm{C}$. No growth was observed at temperatures above $42^{\circ} \mathrm{C}$ within 14 days. At $5{ }^{\circ} \mathrm{C}$, small colonies were seen on the agar plates. The colonies were yellowish, translucent and shiny with entire edges, becoming mucoid after prolonged incubation.

Strains PSD1-4 $4^{\mathrm{T}}$ and PHA3 $-4^{\mathrm{T}}$ shared a number of phenotypic characteristics tested in common, with the following differential characteristics: $\mathrm{pH}$ ranges for growth, tolerance to $\mathrm{NaCl}$ and degradation of Tween 80 . Comparison of physiological and biochemical characteristics also enabled differentiation of each isolate from other representative species of the genus Chryseobacterium (Table 1). Strain PSD1- $4^{\mathrm{T}}$ was shown to inhibit growth of the plant pathogen Fusarium oxysporum, whereas strain PHA3 $-4^{\mathrm{T}}$ exhibited no antifungal activity.

Fatty acid methyl esters were extracted and prepared by the standard protocol of the Sherlock Microbial Identification System (MIDI). The fatty acids analysed by a gas chromatograph (Hewlett Packard 6890) were identified by the Microbial Identification software package (Sasser, 1990). The fatty acid contents of PSD $1-4^{\mathrm{T}}$ and PHA3 $-4^{\mathrm{T}}$ indicated that 13-methlyltetradecanoic acid (iso-C15:0) was the most abundant fatty acid for both strains, which was followed by 3-hydroxy-15-methylhexadecanoic acid (iso-C17:0 3$\mathrm{OH})$ and omega-9-cis-15-methylhexadecenoic acid (isoC17: $1 \omega 9 c$ ) (Table 2). These fatty acid profiles were similar to those of the type strains of other Chryseobacterium species. However, strains PSD $1-4^{\mathrm{T}}$ and PHA3 $-4^{\mathrm{T}}$ differed from each

Table 1. Distinctive phenotypic characteristics of strains PSD1-4 ${ }^{\top}$ and PHA3-4 ${ }^{\top}$ and species of the genus Chryseobacterium

Species: 1, C. soldanellicola (strain PSD1-4 $\left.{ }^{\mathrm{T}}\right) ; 2$, C. taeanense (strain PHA3-4 $\left.{ }^{\mathrm{T}}\right) ; 3$, C. taichungense $(n=1) ; 4, C$. balustinum $(n=1)$; 5 , C. daecheongense $(n=1) ; 6$, C. defluvii $(n=1) ; 7$, C. formosense $(n=1) ; 8$, C. gleum $(n=2)$; 9, C. indologenes $(n=7)$; 10, C. indoltheticum $(n=1) ; 11$, C. joostei $(n=11) ; 12$, C. scophthalmum $(n=2)$. Data for reference species were taken from Kämpfer et al. (2003), Li et al. (2003), Hugo et al. (2003), Kim et al. (2005), Shen et al. (2005) and Young et al. (2005). +, All strains positive; W, weakly positive; -, all strains negative; V, variable; D, delayed; NA, no data available. All species hydrolyse aesculin.

\begin{tabular}{|c|c|c|c|c|c|c|c|c|c|c|c|c|}
\hline Characteristic & 1 & 2 & 3 & 4 & 5 & 6 & 7 & 8 & 9 & 10 & 11 & 12 \\
\hline \multicolumn{13}{|l|}{ Growth on/at: } \\
\hline MacConkey agar & - & - & - & + & - & - & - & + & + & + & + & - \\
\hline $5^{\circ} \mathrm{C}$ & + & + & - & $\mathrm{D}$ & - & - & - & - & - & + & + & $\mathrm{D}$ \\
\hline $37^{\circ} \mathrm{C}$ & + & + & + & + & + & + & - & + & - & + & - & - \\
\hline $42^{\circ} \mathrm{C}$ & - & - & - & - & - & + & - & - & - & - & - & - \\
\hline \multicolumn{13}{|l|}{ Enzyme activities } \\
\hline DNase & - & - & NA & + & NA & NA & $\mathrm{NA}$ & + & + & + & + & + \\
\hline Urease & - & - & - & - & - & - & - & - & - & - & $\mathrm{V}$ & + \\
\hline Nitrate reduction & - & - & - & + & + & - & - & + & - & - & - & - \\
\hline Nitrite reduction & - & - & NA & - & - & + & NA & + & - & - & - & - \\
\hline Tween 80 hydrolysis & - & + & $\mathrm{NA}$ & + & - & NA & - & + & + & + & + & + \\
\hline \multicolumn{13}{|l|}{ Production of: } \\
\hline Hydrogen sulphide & - & - & - & - & - & - & - & - & - & + & - & - \\
\hline Indole & - & - & $\mathrm{W}$ & + & - & + & + & + & + & + & + & - \\
\hline \multicolumn{13}{|l|}{ Acid production from: } \\
\hline L-Arabinose & - & - & - & - & - & - & - & + & - & - & - & - \\
\hline Fructose & - & - & NA & + & + & + & $\mathrm{NA}$ & + & + & - & + & - \\
\hline Glycerol & - & - & $\mathrm{NA}$ & - & + & + & NA & + & + & - & V & - \\
\hline Lactose & - & - & - & - & - & - & $\mathrm{NA}$ & - & - & - & - & - \\
\hline Maltose & - & - & + & - & - & + & - & + & + & + & + & - \\
\hline Mannitol & - & - & - & - & - & - & - & - & - & - & $\mathrm{V}$ & - \\
\hline Trehalose & - & - & + & - & + & + & + & + & + & - & + & + \\
\hline D-Xylose & - & - & + & - & + & - & $\mathrm{W}$ & + & - & - & - & - \\
\hline $\mathrm{G}+\mathrm{C}$ content $(\mathrm{mol} \%)$ & $28 \cdot 8$ & $32 \cdot 1$ & NA & $33 \cdot 1$ & $36 \cdot 6$ & $38 \cdot 8$ & NA & $38 \cdot 0$ & $38 \cdot 5$ & $33 \cdot 8$ & $36 \cdot 8$ & $34 \cdot 2$ \\
\hline
\end{tabular}


Table 2. Fatty acid content (\%) of strains PSD $1-4^{\top}$ and $\mathrm{PHA} 3-4^{\top}$ and species of the genus Chryseobacterium

Species: 1, C. soldanellicola (strain PSD1-4 $\left.{ }^{\mathrm{T}}\right) ; 2$, C. taeanense (strain PHA3-4 ${ }^{\mathrm{T}}$ ); 3, C. taichungense $(n=1) ; 4, C$. balustinum $(n=1) ; 5, C$. daecheongense $(n=1) ; 6$, C. defluvii $(n=1) ; 7$, C. formosense $(n=1) ; 8$, C. gleum $(n=5) ; 9$, C. indologenes $(n=45)$; 10, C. indoltheticum $(n=1)$; 11, C. joostei $(n=11)$; 12, C. scophthalmum $(n=7)$. Data for reference species were taken from Kämpfer et al. (2003), Li et al. (2003), Hugo et al. (2003), Kim et al. (2005), Shen et al. (2005) and Young et al. (2005). tr, Trace (less than 1.0\% of the total); ND, not detected.

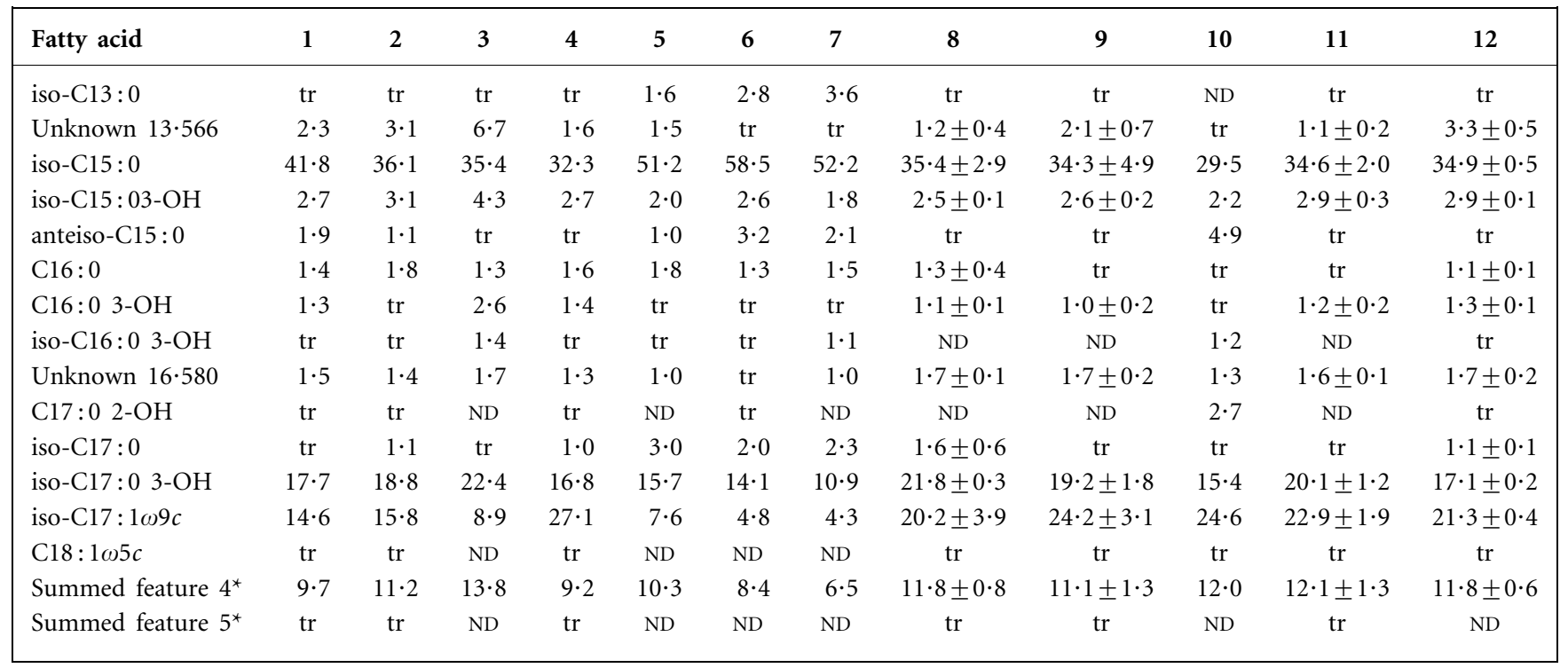

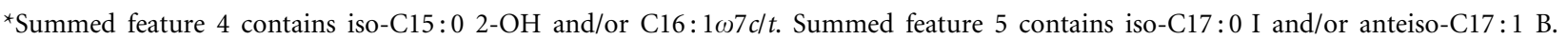

other and from other Chryseobacterium species in relative abundance of shared components (Table 2).

The 16S rRNA gene sequences of strains PSD1- $4^{\mathrm{T}}$ (1426 nucleotides) and PHA3-4 ${ }^{\mathrm{T}}$ (1425 nucleotides) were determined as described previously (Han et al., 2003). The resultant sequences were aligned manually, based on $16 \mathrm{~S}$ rRNA secondary structure, with representative sequences of Chryseobacterium species obtained from the GenBank database. The phylogenetic tree based on the 16S rRNA gene sequences was inferred using the neighbour-joining method (Saitou \& Nei, 1987). Evolutionary distance matrices for the neighbour-joining method were generated according to Kimura's 2-parameter distance model (Kimura, 1980). The resultant neighbour-joining tree topology was evaluated by bootstrap analysis (Felsenstein, 1985) based on 1000 resampled datasets. Alignment with representative sequences of Chryseobacterium and subsequent phylogenetic analyses were carried out using the PHYDIT program (jPHYDIT is available at http://chunlab.snu.ac.kr/jphydit/) as described previously (Han et al., 2003).

The final set of sequence data consisted of 1402 nucleotide positions. Strains PSD $1-4^{\mathrm{T}}$ and PHA3 $-4^{\mathrm{T}}$ shared $96 \cdot 2 \% 16 \mathrm{~S}$ rRNA gene sequence similarity. Strain PSD $1-4^{\mathrm{T}}$ shared between $95 \cdot 2$ and $97 \cdot 2 \%$ similarity with other established Chryseobacterium species, among which $C$. indoltheticum ATCC $27950^{\mathrm{T}}$ was the closest neighbour. The similarity values between strain PHA3- $4^{\mathrm{T}}$ and other type strains of
Chryseobacterium species were in the range $93 \cdot 7-97 \cdot 8 \%, C$. taichungense CC-TWGS1-8 ${ }^{\mathrm{T}}$ being the closest neighbour. The close relationship between the two organisms was reflected by the $100 \%$ bootstrap support and the recovery of the same topology using other algorithms (Fig. 1). However, the phylogenetic tree and DNA-DNA relatedness data clearly indicated that each of the two strains forms a distinct phyletic lineage. The level of DNA-DNA relatedness was determined according to the procedure described by Lim et al. (2003) and the resultant data supported the separation between PSD $1-4^{\mathrm{T}}$ and $C$. indoltheticum ATCC $27950^{\mathrm{T}}$ $(23 \%)$, and also between PHA3-4 ${ }^{\mathrm{T}}$ and C. taichungense CC-TWGS1-8 $8^{\mathrm{T}}(25 \%)$, as the relatedness levels were well below the suggested cut-off value of $70 \%$ for species differentiation.

On the basis of the results of the phenotypic and genotypic study, it is evident that PSD $1-4^{\mathrm{T}}$ and PHA $3-4^{\mathrm{T}}$ should be placed in the genus Chryseobacterium as the type strains of two novel species, for which the names Chryseobacterium soldanellicola sp. nov. and Chryseobacterium taeanense sp. nov. are proposed.

Strains of Chryseobacterium were found to form the second largest group after Pseudomonas among the culturable microbial populations retrieved from the root and rhizosphere of sand-dune plants (Park et al., 2005). Since little information is available on the possible roles of bacteria belonging to Chryseobacterium associated with plants 


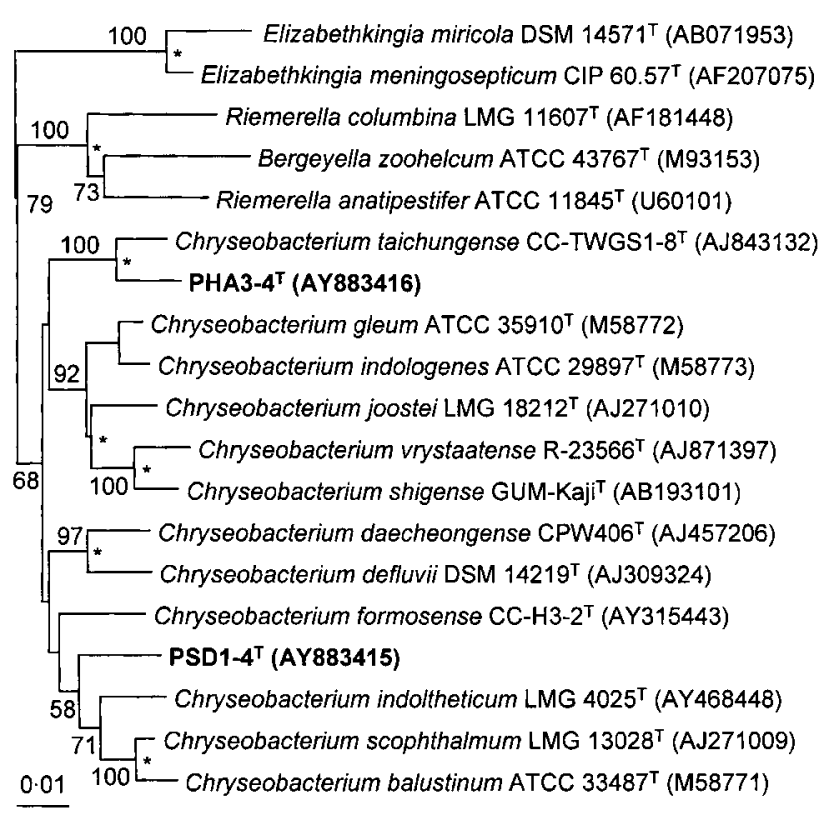

Fig. 1. Neighbour-joining tree based on nearly complete $16 \mathrm{~S}$ rRNA gene sequences showing relationships among strains PSD $1-4^{\top}$ and PHA3 $-4^{\top}$ and other species of the genus Chryseobacterium. The values above each branch indicate the percentage levels of bootstrap support $(>50 \%)$ for the branch point based on 1000 resamplings. The asterisks indicate branches that were also recovered in the maximum-likelihood and maximum-parsimony trees. Bar, 0.01 substitutions per nucleotide position.

(Bernardet et al., 2001; McSpadden Gardener \& Weller, 2001), it is not easy to speculate on their ecological significance to the sand dune vegetation. More detailed studies on these bacteria will be necessary to elucidate their significance in that specific ecosystem.

\section{Description of Chryseobacterium soldanellicola sp. nov.}

Chryseobacterium soldanellicola (sol.da.nel'li.co.la. N.L. n. soldanella the species epithet of a plant belonging to the genus Calystegia; L. suff. verbal n. cola dweller; N.L. masc. n. soldanellicola dweller of Calystegia soldanella).

Cells are non-spore-forming rods. Gram-negative. Good growth is observed on R2A agar, TSA and nutrient agar at $25-30{ }^{\circ} \mathrm{C}$. Grows at $5{ }^{\circ} \mathrm{C}$, but not at $42^{\circ} \mathrm{C}$. No growth is observed on MacConkey agar. Colonies are yellowish, circular and shiny. The $\mathrm{pH}$ range for growth is $\mathrm{pH} 5-7$ and that for optimal growth is $\mathrm{pH}$. Growth occurs aerobically, but not anaerobically. Growth occurs in the presence of $0-4 \%(\mathrm{w} / \mathrm{v}) \mathrm{NaCl}$ within 14 days. The most abundant cellular fatty acids are iso-C15:0 and iso-C17:0 3-OH. Indole, $\mathrm{H}_{2} \mathrm{~S}$ and acetoin are not produced. Nitrate and nitrite are not reduced. Positive for cytochrome oxidase but negative for arginine dihydrolase, lysine decarboxylase, citrate utilization, tryptophan deaminase and urease. Capable of hydrolysing aesculin and gelatin. Weakly assimilates glucose, arabinose, mannose and maltose. The following compounds are utilized as sole carbon sources: $\alpha$-cyclodextrin, dextrin, glycogen, Tween 40 , L-arabinose (weakly), D-fructose, gentiobiose, $\alpha$-D-glucose, maltose, Dmannose, L-rhamnose, D-trehalose, turanose, mono-methyl succinate, acetic acid, D-galacturonic acid, $\alpha$-ketobutyric acid, $\alpha$-ketovaleric acid, propionic acid, L-alanine, L-alanyl glycine, L-asparagine, L-aspartic acid, L-glutamic acid, glycyl L-glutamic acid, L-phenylalanine, L-proline, L-serine, Lthreonine, 2,3-butanediol (weakly) and glycerol (weakly). The following compounds are not utilized: Tween $80, \mathrm{~N}$ acetyl-D-galactosamine, $\mathrm{N}$-acetyl-D-glucosamine, adonitol, D-arabitol, cellobiose, i-erythritol, L-fucose, D-galactose, myo-inositol, $\alpha$-L-lactose, lactulose, mannitol, D-melibiose, methyl $\beta$-D-glucoside, D-psicose, D-raffinose, D-sorbitol, sucrose, xylitol, methyl pyruvate, cis-aconitic acid, citric acid, formic acid, D-galactonic acid lactone, D-gluconic acid, D-glucosaminic acid, D-glucuronic acid, $\alpha$-, $\beta$ - and $\gamma$ hydroxybutyric acid, $p$-hydroxyphenylacetic acid, itaconic acid, $\alpha$-ketoglutaric acid, DL-lactic acid, malonic acid, quinic acid, D-saccharic acid, sebacic acid, succinic acid, bromosuccinic acid, succinamic acid, glucuronamide, alaninamide, D-alanine, glycyl L-aspartic acid, L-histidine, hydroxyL-proline, L-leucine, L-ornithine, L-pyroglutamic acid, D-serine, DL-carnitine, $\gamma$-aminobutyric acid, urocanic acid, inosine, uridine, thymidine, phenylethylamine, putrescine, 2-aminoethanol, DL- $\alpha$-glycerol phosphate, glucose 1phosphate and glucose 6-phosphate. Results from API ZYM tests are given in Table 3 . The $\mathrm{G}+\mathrm{C}$ content is $28 \cdot 8 \mathrm{~mol} \%$.

The type strain is PSD1-4 ${ }^{\mathrm{T}}\left(=\right.$ KCTC $12382^{\mathrm{T}}=\mathrm{NBRC}$ $100864^{\mathrm{T}}$ ), which was isolated from the roots of Calystegia soldanella growing on a coastal area in Tae-an, Korea. The type strain displays antifungal activity against Fusarium oxysporum.

\section{Description of Chryseobacterium taeanense sp. nov.}

Chryseobacterium taeanense (tae.an.en'se. N.L. neut. adj. taeanense of Tae-an, a geographical region in Chungnam, Korea, where the type strain was isolated).

Cells are non-spore-forming rods. Gram-negative. Good growth is observed on R2A agar, TSA and nutrient agar at $25-30{ }^{\circ} \mathrm{C}$. Grows at $5{ }^{\circ} \mathrm{C}$, but not at $42^{\circ} \mathrm{C}$. No growth is observed on MacConkey agar. Colonies are yellowish, circular and shiny. The $\mathrm{pH}$ range for growth is $\mathrm{pH}$ 5-9 and that for optimal growth is $\mathrm{pH}$ 5. Growth occurs aerobically, but not anaerobically. Growth occurs in 0-6\% (w/v) NaCl within 14 days. The most abundant cellular fatty acids are iso-C15:0 and iso-C17:0 3-OH. Indole, $\mathrm{H}_{2} \mathrm{~S}$ and acetoin are not produced. Nitrate and nitrite are not reduced. Positive for cytochrome oxidase but negative for arginine dihydrolase, lysine decarboxylase, citrate utilization, tryptophan deaminase and urease. Capable of hydrolysing 
Table 3. API ZYM profiles of strains PSD1 $-4^{\top}$ and PHA3-4 $4^{\top}$ and other species of the genus Chryseobacterium

Species: 1, C. soldanellicola (strain PSD1-4 $4^{\mathrm{T}}$ ); 2, C. taeanense (strain PHA3-4 ${ }^{\mathrm{T}}$ ); 3, C. taichungense; 4, C. balustinum; 5, C. daecheongense; 6, C. defluvii; 7, C. formosense; 8, C. gleum; 9, C. indologenes; 10, C. indoltheticum; 11, C. joostei; 12, C. scophthalmum. All species showed positive reactions for 2-naphthyl phosphate, 2-naphthyl caprylate, L-leucyl 2-naphthylamide, L-valyl 2-naphthylamide, 2-naphthyl phosphate and naphthol-AS-BI-phosphate and showed negative reactions for 6-Br-2-naphthyl $\alpha$-D-mannopyranoside. Data for strains PSD1-4 ${ }^{\mathrm{T}}$ and PHA3 $-4^{\mathrm{T}}$ and C. taichungense were obtained in this study; those for other reference species were taken from Hugo et al. (2003), Kim et al. (2005) and Young et al. (2005). The intensity of the developed colour was measured on scale from 0 to 5 and interpreted as negative (-) when values ranged between 0 and 1 and positive $(+)$ for values between 2 and 5 (Mudarris et al., 1994).

\begin{tabular}{|c|c|c|c|c|c|c|c|c|c|c|c|c|}
\hline Substrate & 1 & 2 & 3 & 4 & 5 & 6 & 7 & 8 & 9 & 10 & 11 & 12 \\
\hline 2-Naphthyl myristate & - & - & + & - & - & - & - & - & - & - & - & - \\
\hline$N$-Benzoyl-DL-arginine 2-naphthylamide & - & - & + & - & - & - & + & - & - & - & + & + \\
\hline $\mathrm{N}$-Glutaryl-phenylalanine 2-naphthylamide & - & - & + & - & + & + & - & - & + & - & - & - \\
\hline Naphthol-AS-BI $\beta$-D-glucuronide & - & - & + & - & - & - & - & - & - & - & - & - \\
\hline 2-Naphthyl $\alpha$-D-glucopyranoside & + & + & + & + & - & + & - & + & + & + & + & + \\
\hline 6-Br-2-Naphthyl $\beta$-D-glucopyranoside & - & + & + & + & - & - & + & + & - & - & - & - \\
\hline 1-Naphthyl- $N$-acetyl $\beta$-D-glucosaminide & - & - & + & + & + & + & + & + & + & + & + & + \\
\hline 2-Naphthyl $\alpha$-L-fucopyranoside & - & - & - & - & - & - & - & - & - & - & - & - \\
\hline
\end{tabular}

${ }^{\star}$ Weakly positive.

aesculin and gelatin. Weakly assimilates glucose, arabinose, mannose and maltose. The following compounds are utilized as sole carbon sources: $\alpha$-cyclodextrin, dextrin, glycogen, Tween 40, Tween 80, L-arabinose, cellobiose, $\mathrm{D}$-fructose, L-fucose, D-galactose, gentiobiose, $\alpha$-D-glucose, myo-inositol, $\alpha$-D-lactose, lactulose, maltose, mannitol (weakly), D-mannose, methyl $\beta$-D-glucoside, D-psicose, D-raffinose, L-rhamnose, D-sorbitol, sucrose, D-trehalose, turanose, xylitol, methyl pyruvate, monomethyl succinate, cis-aconitic acid, citric acid, formic acid, D-galactonic acid lactone, D-galacturonic acid, D-gluconic acid, D-glucosaminic acid, D-glucuronic acid, $\alpha$-hydroxybutyric acid, $\beta$-hydroxybutyric acid (weakly), itaconic acid, $\alpha$ ketobutyric acid, $\alpha$-ketoglutaric acid, $\alpha$-ketovaleric acid, DL-lactic acid, malonic acid, propionic acid, quinic acid, D-saccharic acid, sebacic acid, succinamic acid, glucuronamide, alaninamide, L-alanine, L-alanyl glycine, L-asparagine, L-aspartic acid, L-glutamic acid, glycyl L-aspartic acid, glycyl L-glutamic acid, hydroxy-L-proline (weakly), L-leucine, Lornithine, L-phenylalanine, L-proline, L-pyroglutamic acid, L-serine, L-threonine, DL-carnitine, inosine (weakly) and uridine (weakly). The following compounds are not utilized; $N$-acetyl-D-galactosamine, $N$-acetyl-D-glucosamine, adonitol, D-arabitol, $i$-erythritol, D-melibiose, acetic acid, $\gamma$ hydroxybutyric acid, $p$-hydroxyphenylacetic acid, succinic acid, bromosuccinic acid, D-alanine, L-histidine, D-serine, $\gamma$-aminobutyric acid, urocanic acid, thymidine, phenylethylamine, putrescine, 2-aminoethanol, 2,3-butanediol, glycerol, DL- $\alpha$-glycerol phosphate, glucose 1-phosphate and glucose 6-phosphate. Results from API ZYM tests are given in Table 3 . The $\mathrm{G}+\mathrm{C}$ content is $32 \cdot 1 \mathrm{~mol} \%$.
The type strain is PHA $3-4^{\mathrm{T}}\left(=\mathrm{KCTC} 12381^{\mathrm{T}}=\mathrm{NBRC}\right.$ $100863^{\mathrm{T}}$ ), which was isolated from the roots of Elymus mollis growing on a coastal area in Tae-an, Korea.

\section{Acknowledgements}

This research was undertaken with the support from the EcoTechnopia 21 Project sponsored by the Ministry of the Environment, Republic of Korea.

\section{References}

Bernardet, J.-F., Hugo, C. \& Bruun, B. (2001). The genus Chryseobacterium. In The Prokaryotes: an Evolving Electronic Resource for the Microbiological Community, 3rd edn, release 3.7. Edited by M. Dworkin et al. New York: Springer. http://link.springer-ny.com/link/ service/books/10125/

de Beer, H. D., Hugo, C. J., Jooste, P. J., Willems, A., Vancanneyt, M., Coenye, T. \& Vandamme, P. (2005). Chryseobacterium vrystaatense sp. nov., isolated from raw chicken in a chicken processing plant. Int J Syst Evol Microbiol 55, 2149-2153.

Felsenstein, J. (1985). Confidence limits on phylogenies: an approach using the bootstrap. Evolution 39, 783-791.

Gerhardt, P., Murray, R. G. E., Wood, W. A. \& Krieg, N. R. (1994). Methods for General and Molecular Bacteriology. Washington, DC: American Society for Microbiology.

Han, S. K., Nedashkovskaya, O. I., Mikhailov, V. V., Kim, S. B. \& Bae, K. S. (2003). Salinibacterium amurskyense gen. nov., sp. nov., a novel genus of the family Microbacteriaceae from the marine environment. Int J Syst Evol Microbiol 53, 2061-2066. 
Hugo, C. J., Segers, P., Hoste, B., Vancanneyt, M. \& Kersters, K. (2003). Chryseobacterium joostei sp. nov., isolated from the dairy environment. Int J Syst Evol Microbiol 53, 771-777.

Kämpfer, P., Dreyer, U., Neef, A., Dott, W. \& Busse, H.-J. (2003). Chryseobacterium defluvii sp. nov., isolated from wastewater. Int J Syst Evol Microbiol 53, 93-97.

Kim, K. K., Bae, H. S., Schumann, P. \& Lee, S. T. (2005). Chryseobacterium daecheongense sp. nov., isolated from freshwater lake sediment. Int J Syst Evol Microbiol 55, 133-138.

Kim, K. K., Kim, M.-K., Lim, J. H., Park, H. Y. \& Lee, S. T. (2005). Transfer of Chryseobacterium meningosepticum and Chryseobacterium miricola to Elizabethkingia gen. nov. as Elizabethkingia meningoseptica comb. nov. and Elizabethkingia miricola comb. nov. Int J Syst Evol Microbiol 55, 1287-1293.

Kimura, M. (1980). A simple method for estimating evolutionary rates of base substitutions through comparative studies of nucleotide sequences. J Mol Evol 16, 111-120.

Li, Y., Kawamura, K., Fujiwara, N., Naka, T., Liu, H., Huang, X., Kobayashi, K. \& Ezaki, T. (2003). Chryseobacterium miricola sp. nov., a novel species isolated from condensation water of space station Mir. Syst Appl Microbiol 26, 523-528.

Lim, Y. W., Baik, K. S., Han, S. K., Kim, S. B. \& Bae, K. S. (2003). Burkholderia sordidicola sp. nov., isolated from the white-rot fungus Phanerochaete sordida. Int J Syst Evol Microbiol 53, 1631-1636.

McSpadden Gardener, B. B. \& Weller, D. M. (2001). Changes in populations of rhizosphere bacteria associated with take-all disease of wheat. Appl Environ Microbiol 67, 4414-4425.
Mudarris, M., Austin, B., Segers, P., Vancanneyt, M., Hoste, B. \& Bernardet, J. F. (1994). Flavobacterium scophthalmum sp. nov., a pathogen of turbot (Scophthalmus maximus L.). Int J Syst Bacteriol 44, 447-453.

Park, M. S., Jung, S. R., Lee, M. S., Kim, K. O., Do, J. O., Lee, K. H., Kim, S. B. \& Bae, K. S. (2005). Isolation and characterization of bacteria associated with two sand dune plant species, Calystegia soldanella and Elymus mollis. J Microbiol 43, 219-227.

Saitou, N. \& Nei, M. (1987). The neighbor-joining method: a new method for reconstructing phylogenetic trees. Mol Biol Evol 4, 406-425.

Sasser, M. (1990). Identification of bacteria by gas chromatography of cellular fatty acids. MIDI Technical Note 101. Newark, DE: MIDI Inc.

Shen, F. T., Kämpfer, P., Young, C. C., Lai, W. A. \& Arun, A. B. (2005). Chryseobacterium taichungense sp. nov., isolated from contaminated soil. Int J Syst Evol Microbiol 55, 1301-1304.

Shimomura, K., Kaji, S. \& Hiraishi, A. (2005). Chryseobacterium shigense sp. nov., a yellow-pigmented, aerobic bacterium isolated from a lactic acid beverage. Int J Syst Evol Microbiol 55, 1903-1906.

Vandamme, P., Bernardet, J.-F., Segers, P., Kersters, K. \& Holmes, B. (1994). New perspectives in the classification of the flavobacteria: description of Chryseobacterium gen. nov., Bergeyella gen. nov., and Empedobacter nom. rev. Int J Syst Bacteriol 44, 827-831.

Young, C. C., Kämpfer, P., Shen, F. T., Lai, W. A. \& Arun, A. B. (2005). Chryseobacterium formosense sp. nov., isolated from the rhizosphere of Lactuca sativa L. (garden lettuce). Int J Syst Evol Microbiol 55, 423-426. 